\title{
Буддизм и донские калмыки-казаки в социокультурном пространстве России
}

\author{
Мерген С. Уланов, Арья А. Андреева \\ Калмыцкий государственный университет им. Б. Б. Городовикова, Российская Федерация
}

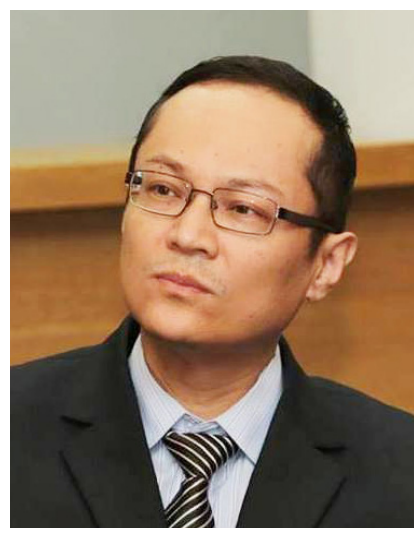

В данной статье рассматриваются особенности истории буддизма у донских калмыков-казаков. Тем самым отмечается, что среди казаков традиционно исторически были представители разных религий. Сама же ситуация становления калмыков-буддистов казаками рассматривается как не типичная.

Исторические события в регионе проживания калмыков в составе российской империи привели к тому, что часть из них в XVII в. переселилась к берегам Дона, где они получили статус казачьих войск. Несмотря на географическую оторванность от основной массы калмыцкого народа и вхождение в состав донского казачества, калмыки-казаки смогли сохранить свою этническую и конфессиональную идентичность. Более того, буддизм стал ключевым фактором сохранения национальной идентичности у калмыков. Именно он выделял их из состава других народов Области Войска Донского, став символом их этнической самобытности и консолидации.

Казачья администрация Дона была в свою очередь заинтересована в калмыках, как значительной военной силе, в силу чего религиозные отличия отходили на второй план. Несмотря на попытки ограничить количество хурулов и калмыцкого духовенства, а

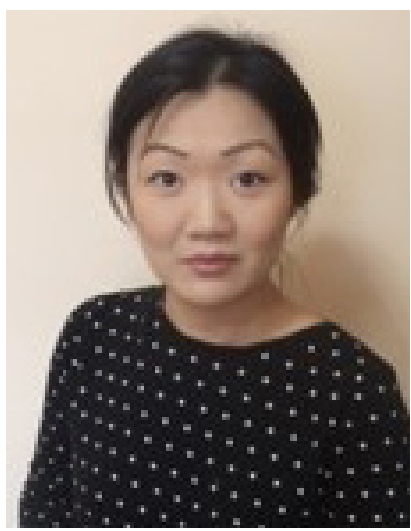
также поставить под контроль буддийскую церковь донских калмыков, последняя представляла собой достаточно сплоченную и организованную силу, влияние которой на калмыцкое население было значительным.

Ключевые слова: буддизм; буддийская церковь; буддийское духовенство; буддизм России; хурул; калмыки; Калмыкия; донские калмыки; калмыцкое казачество; Область Войска Донского; Дон; буддийская идентичность

Подготовлено при финансовой поддержке Российского научного фонда в рамках научного проекта «Россия и буддийский мир в дискурсе философского востоковедения» (грант № 19-18-00118).

\section{Для циттрования:}

Уланов М. С., Андреева А. А. Буддизм и донские калмыки-казаки в социокультурном пространстве России // Новые исследования Тувы. 2021. № 2. С. 100-114. DOI: https://www.doi.org/10.25178/nit.2021.2.9

Уланов Мерген Санджиевич - доктор философских наук, кандидат исторических наук, доцент, профессор кафедры философии и культурологии Калмыцкого государственного университета имени Б. Б. Городовикова. Адрес: 358000, Россия, г. Элиста, ул. Пушкина, д. 11, каб. 111. Тел.: +7 (961) 541-1138. Эл. адрес: ulanov1974@mail.ru

Андреева Арья Александровна - старший преподаватель кафедры калмыцкой литературы и журналистики Калмыцкого государственного университета имени Б. Б. Городовикова. Адрес: 358000, Россия, г. Элиста, ул. Пушкина, д. 11, каб. 111. Тел.: +7 (960) 899-98-88. Эл. адрес: lovely-arya@mail.ru 


\title{
Buddhism and the Don Kalmyk Cossacks in the Sociocultural Space of Russia
}

\author{
Mergen S. Ulanov, Aria A. Andreeva
}

B. B. Gorodovikov Kalmyk State University, Russian Federation

\begin{abstract}
This article examines the features of the history of Buddhism among the Don Kalmyk Cossacks. Thus, it is noted that among the Cossacks there were traditionally and historically followers of different religions. The very situation of the formation of the Kalmyk Buddhists as the Cossacks is considered as atypical.

Historical events in the region inhabited by the Kalmyks as subjects of the Russian Empire resulted in a situation when some of them moved to the banks of the Don in the 17th century, where they received the status of Cossack troops. Despite their geographical isolation from the bulk of the Kalmyk people and integration into the Don Cossack society, the Kalmyk Cossacks managed to preserve their ethnic and confessional identity. Moreover, Buddhism became the overriding factor in retaining the national identity of the Kalmyks. It was Buddhism that was distinguishing them from the other peoples of the Province of the Don Cossack Host, having become a symbol of their ethnic identity and consolidation.

The Don Cossack administration was in turn interested in the Kalmyks as a significant military force, whereby religious differences were fading into the background. Despite attempts to limit the number of khuruls and the Kalmyk clergy, as well as to bring the Buddhist church of the Don Kalmyks under control, the latter was a considerably cohesive and organized force that had a significant influence on the Kalmyk population.
\end{abstract}

Keywords: Buddhism; Buddhist church; Buddhist clergy; Buddhism of Russia; khurul; Kalmyks; Kalmykia; Don Kalmyks; Kalmyk Cossacks; province of the Don Cossack Host; Don; Buddhist identity

\section{Financing}

The article was prepared with support from the Russian Science Foundation, grant no. 19-18-00118, "Russia and the Buddhist World in the Discourse of the Philosophy of Oriental Studies".

\section{For citation:}

Ulanov M. S. and Andreeva A. A. Buddizm i donskie kalmyki-kazaki v sotsiokul'turnom prostranstve Rossii [Buddhism and the Don Kalmyk Cossacks in the Sociocultural Space of Russia]. New Research of Tuva, 2021, no. 2, pp. 100-114. (In Russ.). DOI: https://www.doi.org/10.25178/nit.2021.2.9

ULANOV, Mergen Sandzhievich, Doctor of Philosophy, Candidate of History, Professor, Department of Philosophy and Cultural Studies, B. B. Gorodovikov Kalmyk State University. Postal address: Office 111, 11 Pushkin St., 358000 Elista, Russian Federation. Tel.: +7 (961) 541-11-38. E-mail: ulanov1974@mail.ru

ANDREEVA, Aria Alexsandrovna, Lecturer, Department of Kalmyk literature and journalism, B. B. Gorodovikov Kalmyk State University. Postal address: Office 111, 11 Pushkin St., 358000 Elista, Russian Federation. Tel.: +7 (960) 899-98-88. E-mail: lovelyarya@mail.ru 


\section{Введение}

В современный период особое значение и остроту приобретают вопросы, связанные с духовнонравственным возрождением народов, проживающих на территории России. В связи с этим особую роль играют казачество и его исконные традиции. Особенность казачества состоит в том, что ему на протяжении всей истории его формирования удалось организовать сплоченное демократичное вольнолюбивое общество с уникальными нормами и традициями, с благородной целью охраны государства. В последние три десятилетия набирает обороты процесс восстановления казачества, характер которого сегодня значительно преобразился. Сегодня казачество осуществляет огромную работу по патриотическому, духовно-нравственному воспитанию молодого поколения на фундаменте традиционных ценностей.

В современной научной литературе упрочилось мнение, что казачество имеет отношение только к одному религиозному течению - православному христианству. Нынешние предводители и участники казачьего движения также зачастую отождествляют понятия «казаки», «православие» и «православная церковь». Однако, это мнение ошибочно, если учитывать, что среди казаков всегда были представители разных религий, в значительном количестве. Полиэтничность и поликонфессиональность были характерными особенностями многих казачьих общин России в период их зарождения и становления. Довольно большими среди казаков были группы, связанные с народами, исповедовавшими ислам (башкиры, татары, горцы Кавказа), буддизм (калмыки, буряты), а также местные языческие верования (народы Поволжья, Урала, Сибири, Дальнего Востока). Среди данных этнических групп особо следует отметить донских калмыков, которым в 1694 г. администрация Войска Донского приписало статус казачьих войск.

Целью настоящего исследования является историко-религиоведческий анализ процесса становления и развития буддизма у донских калмыков. В ходе работы над данной темой были использованы как общенаучные, так и специально-исторические методы познания. Междисциплинарный характер предмета исследования с выраженной историко-религиоведческой детерминантой предопределил обращение к методологии, сложившейся в современном религиоведении. Все это позволило нам лучше рассмотреть процесс становления и развития буддизма у донских калмыков-казаков, проследить его взаимосвязь с другими историческими событиями.

Говоря об источниковой базе исследования, необходимо отметить, что одним из наиболее важных видов источников по истории буддизма у донских калмыков являются законодательные акты, опубликованные в Полном собрании законов Российской империи. Особый интерес для нас составляют и статистические материалы, многие из которых нашли отражение в таких сборниках, как «Область Войска Донского по переписи 1873 года» ${ }^{1}$ и «Статистическое описание земли Донских казаков, составленное в 1822-1832 годах»². Некоторую информацию о духовенстве донских калмыков можно найти в дореволюционных справочных изданиях ${ }^{3}$ и региональном периодическом издании православной церкви «Донские епархиальные ведомости». К историческим источникам можно отнести и ряд работ дореволюционных авторов, которые будут рассмотрены в следующем разделе.

\section{Обзор литературы}

Определенный вклад в исследование религии донских калмыков внесли члены Области Войска Донского статистического комитета (1839-1917), которые активно занимались изучением истории и этнографии населения Дона, в том числе и калмыков. Так, несколько статей о жизни, традициях и обычаях донских калмыков принадлежат перу известного краеведа и члена статистического комитета Ф. К. Траилина. В 1872 г. материалы данных работ были объединены и изданы в его книге «Санскринкурэдэ. Священное калмыцкое изображение. Сведения о донских калмыках» (Траилин, 1872). Некоторые сведения о буддизме у донских калмыков содержатся и в книге члена-секретаря Донского статистического комитета С. Ф. Номикосова (Номикосов, 1884).

\footnotetext{
${ }^{1}$ Область Войска Донского по переписи 1873 года. Издание областного Войска Донского Статистического комитета / под ред. члена-секретаря С. Номикосова. Вып. 1. Новочеркасск: Областная Войска Донского Типография, 1879.145 с.

${ }^{2}$ Статистическое описание земли Донских казаков, составленное в 1822-1832 годах. Новочеркасск : Тип. Войска Донского, 1891. 301 с.

${ }^{3}$ Памятная книжка Области войска Донского на 1904 год. Новочеркасск: Областная Войска Донского типография и Частная Донская типография, 1904. 582 с.
} 
В 1873 г. была издана статья члена Донского статистического комитета и преподавателя по классу богословских наук Донской духовной семинарии А. Л. Крылова «Умственное и нравственное развитие Донских калмыков и особенности их быта», вышедшая одновременно отдельным оттиском (Крылов, 1873). Работа Крылова знакомит с нравами и религиозным миросозерцанием донских калмыков.

Значительный интерес для нас представляет исследование помощника председателя Областного правления Войска Донского полковника Н. А. Маслаковца «Физическое и статистическое описание кочевья донских калмыков» (Маслаковец, 1874). Несмотря на то, что главное внимание в нем уделено состоянию сельского хозяйства и административному устройству донских калмыцких кочевий, здесь есть ценные сведения, касающиеся калмыцких хурулов и духовенства на Дону.

Сведения о религии донских калмыков и попытках их христианизации можно встретить в работе иеромонаха Гурия «Донские калмыки и история их христианского просвещения по трудам Казанского миссионерского съезда» (Гурий, 1911). Несмотря на то, что труд посвящен истории христианизации донских калмыков, в нем содержатся сведения и о положении местной буддийской церкви.

Некоторую информацию об истории буддизма у донских калмыков можно обнаружить также в работах В. Б. Броневского (Броневский, 1834), С. Браиловского и Н. Немцова (Браиловский, Немцов, 1901), С. Павловского (Павловский, 1911), И. И. Попова (Попов, 1919) и др.

В целом, авторы, связанные с православной церковью (А. Л. Крылов, Гурий) и царской администрацией (С. Ф. Номикосов, Н. А. Маслаковец), занимали достаточно жесткую позицию в отношении калмыцкого буддийского духовенства, критически отзываясь о его роли в жизни донских калмыков.

С другой стороны, авторы, представлявшие калмыцкую национальную интеллигенцию, выступали с иных позиций. Так, калмыцкий офицер и путешественник Н. Э. Уланов, описывая жизнь буддийского духовенства в труде «Буддийско-ламаиское духовенство донских калмыков, его современное положение», обращает внимание на его просветительскую деятельность и позитивную роль в общественной жизни (Уланов, 1902). Калмыцкое буддийское духовенство, по его мнению, являлось носителем национального самосознания. Калмыцкие священнослужители в его работе предстают как просветители и наставники молодого поколения калмыков. В них он видел значительную силу, способную сохранить национальную культуру и противостоять ассимиляции калмыков. Лама-лекарь и путешественник Д. Ульянов в своей книге «Предсказания Будды о Доме Романовых и краткий очерк моих путешествий в Тибет в 1904-1905 гг.» (Ульянов, 1913), кроме повествования о своем паломничестве в Тибет, предоставляет здесь также некоторые данные о донских калмыках и их буддийском духовенстве.

В советский период история буддизма у донских калмыков почти не изучалась. Некоторые сведения о роли буддизма в жизни донских калмыков и отдельные статистические данные о численности духовенства можно найти в работе Х. Б. Канукова «Будда-ламаизм и его последствия», посвященной критике данной конфессии (Кануков, 1928).

Из работ постсоветского периода можно выделить труды таких калмыцких ученых, как К. П. Шовунов, Г. Ш. Доржиева, К. Н. Максимов. В труде К. П. Шовунова «Калмыки в составе российского казачества» (Шовунов, 1992) рассматривается история появления калмыцких казачьих поселений и социально-экономическое состояние калмыков-казаков в дореволюционный период. Один из подразделов посвящен религии донских калмыков. В монографиях Г. Ш. Дорджиевой (Дорджиева, 1995, 2012), посвященных истории религиозной политики правительства Российской империи по отношению к буддизму в Калмыкии, затрагиваются и вопросы буддизма у донских калмыков. В монографии К. Н. Максимова «Калмыки в составе донского казачества (XVII - середина XX в.)» (Максимов, 2016) содержатся статистические сведения о численности калмыцкого буддийского духовенства и хурулов в разные периоды истории донских калмыков.

Материалы по истории буддизма у донских калмыков можно найти в специальных разделах трехтомной «Истории Калмыкии с древнейших времен до наших дней», посвященных калмыцким этническим группам на Дону и буддизму в Калмыкии, подготовленных соответственно У. Б. Очировым и Г. Ш. Дорджиевой (История Калмыкии ..., 2009ab), а также в работе Э. П. Бакаевой (Бакаева, 1994).

Из трудов зарубежных авторов можно отметить работу американского ученого калмыцкого происхождения А.Э.Борманджинова «Ламы калмыцкого народа:ламы донских калмыков» (Борманджинов, 1997), которая представляет собой краткий очерк жизни и деятельности духовных глав калмыков Дона.

Следует также отметить очерк американского калмыка Кольдоги Содмона (С. С. Кульдинова) «Судьба донских калмыков, их веры и духовенства» (Кольдонга Содном, 2018). Значительное место в работе 
занимает материал, посвященный калмыцкому духовенству, в частности Бакше М. Борманджинову. В то же время часть фактов, изложенных здесь, основана на народных сказаниях и не имеет документального подтверждения.

Другой американский исследователь калмыцкого происхождения Е. С. Ремилева в книге «Ойратмонголы. Обзор истории европейских калмыков» (Ремилева, 2010) затрагивает проблему борьбы буддийского духовенства против русификаторской политики царского правительства, уделяя особое внимание истории жизни таких известных иерархов донских калмыков, как А. Чубанов и М. Борманжинов.

Несмотря на немалое число научных работ, в которых рассматривается история донских калмыков, тема бытования буддизма на Дону остается малоисследованной. Сегодня ощущается настоятельная необходимость в систематизации, обобщении и анализе имеющихся эмпирических данных по данной тематике, что и определяет научную новизну работы.

\section{Появление калмыков на Дону и оформление у них буддийской церковной организации}

Говоря о появлении калмыков на Дону, необходимо отметить, что еще в середине XVII в. группа ойратов перекочевала на земли Поволжья, вошла в состав Российской империи и стала именоваться калмыками. Калмыки в социокультурном смысле представляли собой автономное, самостоятельное сообщество, сплоченное единым этническим полем и духовно объединенное на основе буддизма (подр.: Максимов, 2000, 2002; Цюрюмов, 2007).

С увеличением населения в Калмыцком ханстве (XVII-XVIII) естественно возрастало и поголовье скота, в результате чего происходила деградация пастбищ и уменьшение пригодных для кочевий земель. В связи с этим отдельные группы калмыков, кочевавшие в западной части ханства, все чаще начали обращать свой взор на запад, в сторону донских степей, славившихся свои хорошим травостоем и изобилием водных источников. Как пишет К. П. Шовунов, первые кочевья калмыков на Дону появились в 1670-м году, когда здесь нашёл пристанище тогоутский улус тайши Бока (Шовунов, 1992: 36). После них на постоянное проживание сюда перекочевало еще некоторое количество групп калмыков. В 1690 г. после откочевки на Дон улусов Четеря и Батыр-Черкеса, донским калмыкам были переданы степные территории между реками Дон и Донец. Обживаясь на новой земле, калмыки организовали для отправления буддийского культа мобильный кибиточный хурул (Максимов, 2016: 45).

В 1694 г. Войско Донское приписало донским калмыкам статус казачьих войск. Теперь эти сообщества калмыков, получивших название «юртовых», должны были нести казачью службу, за что получали постоянное жалованье и территории под пастбища. Донские калмыки сохраняли традиционный кочевой уклад жизни и в большинстве своем приверженность буддийскому вероисповеданию, в отличие от большинства казаков (История Калмыкии ..., 2009а: 626). При этом, по мнению К. Н. Максимова, калмыки были окончательно причислены к донскому казачьему войску в статусе военно-служилого сословия только почти через столетие, по именному указу Павла I от 16 февраля 1799 г. (Максимов, 2016: 82).

В 1803 г. на Дон были переселены калмыки, которые ранее кочевали на Новой Днепровской линии. Их общая численность в тот период достигала трех тысяч человек. Казаки из бывших Чугуевского и Беляевского поселений сформировали на Дону Балдырскую и Беляевскую сотни. Почти все эти калмыки открыто исповедовали буддизм, о чем свидетельствуют данные переписей (там же: 646). Так, Н. А. Маслаковец отмечает, что, по данным V ревизии (1794-1796 гг.), из 406 мужчин-калмыков Беляевского поселения только 79 считались крещеными. После же переселения их на Дон к местным калмыкам все беляевские христиане постепенно перешли в буддизм (Маслаковец, 1874: 43). Даже калмыки Чугуевского поселения, в основном крещеные, после переселения стали открыто исповедовать буддизм (История Калмыкии..., 2009а: 646). Подобного рода примеры в Российской империи того времени были крайне редки.

Следует отметить, что до начала XIX в. казачья войсковая администрация не вмешивалась во внутренние дела калмыцкого населения, в том числе и в религиозную жизнь. В силу этого информации

${ }^{1}$ Подушные переписи («ревизии») - переписи, проводившиеся на основе новой учетной единицы - мужских душ вместо «тяглового двора», использовавшегося в Русском государстве в XVI-XVII веках. Подушные переписи стали проводить с 1718 г. при Петре I. Всего было проведено 10 ревизий. 
об истории буддизма у донских калмыков в XVIII столетии крайне мало. Известно, однако, что большинство известных хурулов донских калмыков были основаны именно в XVIII в. Хурулы в этот период были кочевыми и кочевали вместе со своими прихожанами. Каждая сотня имела свой хурул, располагавшийся в кибитках. Подробные данные о хурулах донских калмыков стали появляться только в XIX в. в связи с реорганизацией их общественного устройства и управления (Дорджиева, 1995: 88).

Определенный контроль над религиозной жизнью донских калмыков был установлен только в начале XIX в., после того, как они в 1803 г., по решению атамана М. И. Платова, были переселены в Задонские степи, где в 1806 г. был сформирован специальный Калмыцкий округ, переименованный в 1884 г. в Сальский округ. Этот район, расположенный южнее Дона, стал для донских калмыков местом постоянного обитания. В трех калмыцких улусах (Верхнем, Среднем и Нижнем) было учреждено 13 сотен (аймаков), которые, в свою очередь, делились на хотоны.

Известно, что у донских калмыков был свой религиозный иерарх - Бакша (Лама), который не подчинялся Ламе калмыцкого народа, но был подотчетен царской администрации. Бакша, в частности, подчинялся войсковому атаману по вопросам, связанным с утверждением хурульных штатов.

Таким образом, особенность буддизма у донских калмыков на данном этапе состояла в том, что они обладали значительной самостоятельностью в религиозных делах и не были в духовной юрисдикции Ламы калмыцкого народа.

\section{Установление контроля над буддийской церковью донских калмыков и политика ограничения количества духовенства}

Войсковая казачья администрация пыталась препятствовать увеличению числа буддийских священнослужителей-калмыков, ссылаясь на то, что это значительно сокращает число казаков, несущих здесь военную службу. Так, в 1821 г. наказной атаман Донского казачьего войска А. В. Иловайский своим распоряжением сократил штат ламаистского духовенства до 52 человек (по 4 на сотню), но калмыцкое духовенство добилось отмены данного решения в Петербурге (История Калмыкии..., 2009a: 647).

В 30-е гг. ХІХ столетия вновь стал вопрос о сокращении численности буддийских храмов и духовенства. Войсковой администрацией было решено сократить количество буддийских священнослужителей в каждом хуруле до 12 человек, что понималось как необходимый минимум для совершения религиозных служб. При этом решение по каждому конкретному священнослужителю должен был выносить Бакша, который сам вынужден был сокращать штат местного духовенства. Кроме того, согласно новым предписаниям, обязательным условием для утверждения в сан калмыцкого духовенства стало знание русского языка (История Калмыкии ..., 2009b: 248).

В 1835 г. вышло «Положение об управлении Донского войска», в котором затрагивался вопрос о судебных полномочиях буддийского духовенства. Указывалось, что калмыцкие ламы могут рассматривать только вопросы, связанные с религиозными и внутрисемейными делами. Исключение составляли гражданские дела с недостатком улик и доказательств ${ }^{1}$.

В 1843 г. император Николай II утвердил следующую процедуру избрания Бакши донских калмыков. Он постановил, чтобы калмыцкие сотни большинством голосов избирали трех кандидатов, из которых наказной атаман выбирал одного и утверждал на пост Бакши². Эта процедура избрания духовного первоиерарха сохранялась у донских калмыков до революционных событий XX в.

Следует отметить, что ограничения штата буддийского духовенства, введенные Войсковым правлением, не выполнялись строго. Так, например, в конце 40-х гг. XIX в. насчитывалось 236 духовных лиц, что значительно превышало максимальное число священнослужителей в расчете на один хурул (там же: 249).

В 1849 г. Военный совет Войска Донского вновь попытался ограничить количество буддийского духовенства, приказав наказному атаману не разрешать увеличения количества хурулов и священнослужителей сверх установленного количества в 12 человек. В результате принятых мер Бакше Д. Ганджикову удалось в течение 1850 г. привести штаты духовенства в соответствие с постановлением Военного совета (Максимов, 2016: 230-231).

${ }^{1}$ Полное собрание законов Российской империи. СПб. : Тип. ІІ Отделения Собственной Его Императорского Величества Канцелярии, 1836. Собрание 2. Т. Х. Отделение 1.918 с. С. 633.

${ }^{2}$ Полное собрание законов Российской империи. СПб. : Тип. II Отделения Собственной Его Императорского Величества Канцелярии, 1844. Собрание 2. T. XVIII. Отделение 1. 842 с. С. 771. 
Согласно переписи 1859 г. в 5 калмыцких сотнях (аймаках) уже существовали крупные деревянные хурулы, в остальных 8 сотнях были только кочевые хурулы в форме кибиток. Общее количество штатных духовных лиц здесь насчитывало 176 человек (Максимов, 2016: 246-247).

$\mathrm{B}$ «Статистическом описании кочевьев донских калмыков» действительного члена статистического комитета Н. А. Маслаковца, со ссылкой на данные, собранные калмыцким правлением в 1870 г., отмечается, что кроме положенных по штату 167 духовных лиц у калмыков также было 67 заштатных (выслуживших срок) и 419 сверхштатных буддийских священников, т. е. всего 653 человека духовного звания (Маслаковец, 1874: 43). Естественно, что при таком положении дел религиозность калмыков была достаточно высока, а православной миссии у калмыков противостояла значительная сплоченная и организованная группа буддийских священнослужителей.

В 1873 г. после смерти Бакши К. Баджугинова по предложению наказного атамана с целью усиления контроля над буддийской общиной должность Бакши донских калмыков была упразднена, а его полномочия были переданы старшим гелюнгам (настоятелям) в аймачных хурулах (История Калмыкии ..., 2009b: 249).

По переписи 1873 г. в Калмыцком округе проживало 20997 человек. Примечательно, что в данных переписи по религиозному статусу среди коренного населения округа не нашлось православных, все были отнесены к «ламайцам», хотя ко времени проведения переписи на Дону находилось достаточно много крещеных калмыков-казаков, что, вероятно, говорит о формальном переходе в христианство (Максимов, 2016: 255).

В 1875 г. в Донском войске получил распространение новый способ организации калмыцкого духовенства, по которому оно вместе с казаками стало военнообязанным. Вопрос об уменьшении количества 13 сотен повлёк за собой сокращение количества хурулов в 1877 г. Однако донские калмыки просили местную администрацию оставить им все 14 хурулов. В результате 17 декабря 1880 г. было принято компромиссное решение: калмыкам разрешили оставить уже 10 хурулов. В последующие годы благодаря усилиям ламы Аркада Чубанова количество хурулов увеличилось (История Калмыкии ... , 2009b: 249).

По данным секретаря Донского статистического комитета С. В. Номикосова, в 1881 г. население калмыков составляло $2 \%$ от общего числа жителей области. Собственно штатных духовных лиц, по официальным сведениям, насчитывалось 94 человека, «в действительности штатных и не штатных должно быть около 650 на 28659 душ» (Номикосов, 1884: 221).

Согласно переписи 1897 г. на Дону проживало 32283 калмыка (мужчин - 16 689, женщин - 15 594), из них 29349 - в Сальском округе, где служили 137 человек духовного звания. В ходе переписи все калмыки Сальского округа признали, что владеют калмыцким языком и исповедуют буддизм (Максимов, 2016: 286). К этому времени в трех калмыцких улусах на Дону имелось 13 хурулов (Бакаева, 1994: 35).

K началу XX века основная масса донских калмыков перешла к оседлому образу жизни, но сохранила свою культуру и религию. Все донские калмыки являлись казаками, несли положенные обязанности и повинности, включая военные, и пользовались соответствующими привилегиями.

\section{Положение буддийской церкви донских калмыков в начале XX века}

Известно, что донские калмыки не единожды безрезультатно просили царское правительство об освобождении местного буддийского духовенства от военной повинности. «Однако начавшиеся революционные события, а также принятие Указа «Об укреплении начал веротерпимости» (17 апреля 1905 г.) и Манифеста «Об усовершенствовании государственного порядка» (17 октября 1905 г.) заставили правительство пойти на ряд уступок. Уже в 1905 г. калмыцкое духовенство Области Войска Донского освобождалось от несения воинской службы» (История Калмыкии ..., 2009b: 249).

Еще за несколько лет до этого, в 1903 г. буддийское духовенство донских калмыков получило разрешение на избрание Бакши. После проведения выборов Бакшой донских калмыков стал Менке Борманжинов (1855-1919), утвержденный на эту должность в 1902 г. с разрешения войскового наказного атамана, генерал-лейтенанта К. К. Максимовича. Он был главой буддийских священников донских калмыков до 1919 г. (Максимов, 2016: 302-303). В книгах встречается точка зрения, что он был назначен на эту должность самим императором Николаем II (Павловский, 1911: 1006), однако официальных документов, подтверждающих данный факт нет. 
Известно, что Лама Борманжинов в 1908 г., в год 300-летия дома Романовых, на юбилейных торжествах в Петербурге возглавлял делегацию донских калмыков. Кроме того, М. Борманжинов посещал Северо-Восточный Тибет и несколько раз с целью изучения положений буддийской мысли и процесса постижения буддийской философии посещал ургинского ламу Джебзун Дамба-хутухту, который даровал ему титул Пандита.

Лама Борманжинов также основал в Денисовском хуруле школу буддийской философии Цанид Чооря и намеревался сделать доступными основы учения Будды не только для своих учеников, но и для простых людей, для чего издавал популярные брошюры о буддийском вероучении на калмыцком языке (А. М. Позднеев ..., 2017: 68).

Самым известным из его учеников был лама Лувсан-Шарап Тепкин (1875-1949), который, будучи настоятелем Денисовского хурула в 1909 г. отправился для учебы в Лхасу, где он пробыл до 1922 г. За более чем десятилетнее пребывание в Тибете Лувсан-Шарап прошел полный курс буддийской академии, достиг высокого уровня в изучении буддийской философии, монгольского и тибетского языков. Он также достиг довольно высокого положения при дворе Его Святейшества Далай-ламы XIII - состоял сойбуном (советником) по делам управления Тибета. В 1922 г., выполняя поручение Его Святейшества Далай-ламы XIII и помогая возвращению советской дипломатической миссии во главе с донским калмыком В. А. Хомутниковым из Тибета, Л.-Ш. Тепкин вернулся в Россию, где позже был избран Ламой калмыцкого народа (Алексеева, 2002: 52-53).

В 1911 г. вступило в силу «Временное Положение о службе Багши (Ламы) донских калмыков», утвержденное императором и одобренное Государственной Думой, которое регламентировало права и обязанности духовного иерарха калмыков-казаков Дона. Во Временном Положении определялись следующие полномочия Багши: следить за внешним видом хурулов и моральным обликом проживающих в них священников; наказывать священников, уличённых в недобросовестном исполнении своих обязанностей; определять в духовное звание; вести список калмыцкого духовенства;ходатайствовать о разрешении постройки новых хурулов; рассматривать, по правилам буддийского вероучения, семейно-брачные дела калмыков ${ }^{1}$.

По свидетельству С. Браиловского и Н. Немцева, несколько раз посещавших земли донских калмыков в самом конце XIX в., хурулы к тому времени у них были стационарными. Духовенство донских калмыков представляло собой священнослужителей, принявших монашеские обеты. Исследователи отмечают, что духовенство донских калмыков, также, как и у их астраханских сородичей, делилось на манджиков (послушников), гецулов и гелюнгов. Каждый гелюнг жил на свои средства, которые составляли подаяния прихожан и помощь светских родных. Некоторые из них были достаточно зажиточными людьми и имели по несколько сот голов скота (лошадей и овец). Из среды наиболее богатых и почтенных гелюнгов избирались настоятели монастырей бакши, которые обладали большими полномочиями в хуруле и пользовались среди калмыков болышим уважением. Бакши получали большую часть доходов хурула, при этом являясь ответственными за поведение монахов перед войсковым начальством. Манжики составляли своеобразную свиту или прислугу у бакшей и гелюнгов. Учась тибетской грамоте и правилам богослужения, они главным образом вели хозяйство гелюнгов, при которых и жили (Браиловский, Немцов, 1901: 724).

В целом же, период начала XX века был отмечен определенным религиозным подъемом у калмыков, что связано, как с политикой уступок со стороны властей, так и с активной просветительской деятельностью Бакши донских калмыков М. Борманжинова.

\section{Буддизм в системе ментальности донских калмыков}

Следует отметить, что буддизм как господствующая религия и кочевой быт сформировали у калмыков специфическую ментальность. По мнению некоторых исследователей начала XX в., донских калмыков отличали высокие морально-нравственные устои (Попов, 1919: 308). Православный миссионер А. Л. Крылов писал, что у калмыков нет примеров голодной смерти, в то время как подобные случаи имели место в тогдашней Европе. «У них нет даже нищих, - писал он, - тогда как в самой маленькой нашей деревне это неизбежно» (Крылов, 1873: 29). Даже такой распространенный порок, как пьянство, отмечал Л. Крылов, среди донских калмыков проявлялся в меньшей степени, чем у русских крестьян:

${ }^{1}$ Полное собрание законов Российской империи. СПб. : Государственная типография, 1911. Собрание 3. T. XXXI. Отделение 1.842 с. С. 355. 
«...у калмыков не было примеров убийства в пьяном виде, как нередко у нас бывает, нет пьяниц в том смысле, как мы понимаем их» (там же: 33).

Сведений о миссионерской деятельности русской православной церкви среди донских калмыков до второй половины XIX века крайне мало. И известно, что она особых успехов не имела. Были лишь единичные случаи крещения. В 1871 г. был открыт Донской епархиальный комитет православного миссионерского общества, одним из направлений работы которого должна была стать христианизация калмыков. Так в 1880 г. в слободе Ильинка был открыт приют для детей донских калмыков, где в разное время проживало несколько мальчиков. Многие воспитанники приюта по разным причинам покидали его и не возвращались. Ни один из воспитанников данного заведения так и не стал миссионером (Дорджиева, 1995: 112-113). В 1888 г. в хуторе Плетнева была открыта церковно-приходская школа, где обучалось от 16 до 25 калмыцких мальчиков. Однако, вскоре школа была закрыта из-за нежелания родителей продолжать обучение детей. Подобная участь была и у других приходских школ, открытых для донских калмыков. Попытки приглашения готовых миссионеров также оказались неудачными. Несмотря на то, что в станице Платовской была открыта церковь и миссионерский стан, многие миссионеры, сталкиваясь с сопротивлением калмыцкого населения и местного буддийского духовенства, просто оставляли свой пост (там же: 113-114).

В условиях иноэтнического, инокультурного окружения буддизм стал важным фактором сохранения национальной идентичности у калмыков, особой формой трансляции этничности и национальных традиций. Неслучайно, современники отмечали высокую религиозность калмыков. Представитель калмыцкой национальной интеллигенции начала XX в. Н. Э. Уланов указывал на то, что донские калмыки по-прежнему оставались ревностными буддистами. Большая часть калмыков-казаков была «крайне привержена к вере своих предков и исполнена чувства благоговения к родному духовенству» (Уланов, 1902: 5).

Этот же факт подтверждали и православные миссионеры. Так иеромонах Гурий отмечал особую привязанность донских калмыков

«К национальной религии, в которой хотя рядовые калмыки и мало что понимают по отсутствию средств к ознакомлению с истинами религиозного учения, - но тем не менее благоговеют пред духовенством носителями религиозного сознания, пред номами, т. е. священными книгами, написанными на тибетском языке и частью в переводах на мало доступном пониманию калмыцком (язык подстрочных переводов), пред хурулами, наполненными изображениями бурханов, которых не только простой мирянин, калмык, но и редкий гелюн может назвать всех по именам. Все это дорого народу, потому что он веками сжился с этим, его быт и религия - плоть и кровь его» (Гурий, 1911: 7-8).

С. Павловский в «Кратких сведениях о донских калмыках» также отмечает преданность донских калмыков буддизму: донские калмыки, пишет он, «исповедуют ламаизм и своей вере очень преданы, хотя и мало ее знают, исполняя только обрядовую ее сторону. Случаи обращения калмыков в православную веру бывают очень редки и носят характер случайности» (Павловский, 1911: 1006).

В то же время современники подчеркивали, что при значительном числе духовенства на душу населения калмыки крайне плохо знали правила своей религии. Так, С. Ф. Номикосов отмечал, что донские калмыки считают духовенство обязанным читать молитвы за весь народ, который в ответ должен содержать их за это. Религиозная практика же заключалась главным образом в присутствии на праздничных молебнах и чтении несколько раз в день мантры «Ом мани падме хум». Поскольку священный канон калмыков написан на тибетском языке, доступном пониманию только ученых-лам, то простой народ мог усвоить религиозные понятия только через толкования лам, которые обычно ограничивались чтением молитв на непонятном народу тибетском языке (Номикосов, 1884: 571-572). Впрочем, подобное индифферентное отношение к религии автор отмечает и у значительной части православного населения региона (там же: 569).

Необходимо иметь в виду, что географическая удаленность территории кочевания донских калмыков от Тибета и Монголии не могла пройти бесследно для функционирования местной буддийской церкви. За века культурного отчуждения от буддийских центров, уровень познаний буддийским духовенством сильно упал, а само оно стало стремиться обладать в чрезмерной мере частной собственностью. Одно это уже противоречило монашескому уставу «Виная» и по статьям Монголоойратского права 1640 г. монах не имел права обладать ничем иным, кроме самых необходимых личных вещей, а все более ценное имущество, как например строения, являлось собственностью сангхи (подр.: Ulanov, Badmaev, Holland, 2017; Уланов, Бадмаев, 2017). 
В то же время монголовед А. М. Позднеев, говоря о донских калмыках, отмечал, что «набожность составляет самую отличительную и характеризующую черту калмыка, и по этой своей особенности калмыки обыкновенно проводят свои “мацаки”, или дни поста, т. е. 8; 15 и 30-е число каждого месяца, в молитве о богомыслии, причем последнее чаще всего достигается чтением книги “Тарба-чэнбо" и “Дордже-джодба"» (А. М. Позднеев ..., 2017: 73). Здесь необходимо указать, что в начале XX века у донских калмыков происходил процесс духовного возрождения, связанный с просветительской деятельностью Ламы донских калмыков М. Борманжинова, благодаря чему значительно вырос уровень религиозного образования у священнослужителей и даже мирян.

Таким образом, можно отметить, что буддизм занимал важное место в системе ментальности донских калмыков, являясь значимым фактором этнической самоидентификации, специфической формой трансляции национальных обычаев и традиций. Роль религии как фактора сохранения этнической идентичности особо возрастала в связи с тем, что донские калмыки-калмыки казаки проживали в своеобразном анклаве, окруженном почти со всех сторон иноязычным и иноконфессиональным населением.

\section{Драматическая судьба буддизма донских калмыков в ХХ веке}

Октябрьская революция 1917 г. и последовавшая Гражданская война имели трагические последствия как для донских калмыков вообще, так и для их буддийской церкви. Почти все хурулы на Дону пострадали от действий большевистских отрядов, многие представители духовенства были уничтожены, часть их эмигрировала за границу вместе с отступающей Белой гвардией. В то же время в период Гражданской войны в 1918 г. главой казачества Красновым был закреплён флаг Войска Донского, на котором синий цвет олицетворял донских казаков, желтый - казаков-калмыков, а красный - донских крестьян. Как известно, желтый цвет для калмыков связан с семантикой желтошапочной школы Гелуг, господствовавшей не только в Тибете, но и Монголии, а также у калмыков, бурят и тувинцев.

В 1920-1930-е годы почти все уцелевшие ранее ламы донских калмыков подверглись репрессиям. Боевые действия на Дону в годы Второй мировой войны и последовавшая депортация калмыков привели к полному упадку буддизма на Дону. После реабилитации калмыцкого народа и возращения его на Родину, почти все донские калмыки обосновались на территории восстановленной Калмыцкой ACCP.

В условиях отсутствия буддийских храмов на территории республики среди выходцев из донских

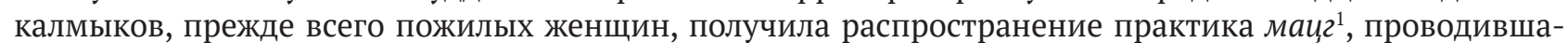
яся в домах верующих. Данная практика включала в себя соблюдение в течение одного дня нескольких буддийских обетов и коллективное начитывание мантр и молитв во время буддийских праздников и в специальные дни по лунному календарю (Уланов, Бадмаев, 2020: 203). И хотя в общины, связанные с практикой мацг, входили представительницы разных этнических групп калмыцкого народа, ведущую роль здесь играли именно выходцы из донских калмыков.

Особое место в истории донских калмыков занимает их эмиграция на Запад. В годы Гражданской войны и Второй мировой значительная часть донских калмыков в силу разных причин вынуждена была эмигрировать на Запад, в Европу, а затем в Америку. Вместе с ними в эмиграцию попали и некоторые ламы, которым удалось сохранить религиозные тексты и утварь. В тяжелых условиях эмиграции буддизм стал важнейшей духовной опорой калмыцких беженцев с донских степей. Функцию хурулов нередко выполняли обустроенные под храмы квартиры или молельные дома (Гучинова, 2004: 238).

В 1929 г. в Белграде силами разных субэтнических групп калмыков был открыт буддийский храм, действовавший до 1944 г. В 1955 г. вскоре после перемещения большей части калмыцкой эмиграции в США силами выходцев из донских калмыков в г. Хауэлл был построен храм Барун-хурул или Олна газар (тиб. название Таши-лумпо), ставший культурным центром калмыцкой эмиграции (Бакаева, 2019). Настоятелем Барун-хурула до 1964 г. был Зодьба-бакша (Зодьба Бурульдинов), который оставил написанную им на тодо бичиг рукопись истории хурулов донских калмыков.

Судьба Зодьба-ламы очень интересна. Известно, что он был репрессирован, отбывал срок на строительстве Беломорско-Балтийского канала, был освобожден в 1935-1936 гг., затем перебрался в Элисту.

\footnotetext{
${ }^{1}$ Мац̨ (калм.) - пост, день поста. Принятие обетов мацъ (тиб. соджонг) - явление, характерное для буддистов тибето-монгольского буддизма. В Калмыкии данную традицию сохраняли в основном пожилые женщины, которых в народе называли мацгта эмгчуд - «бабушки, соблюдающие обеты мацг».
} 
Во время войны он оказался в лагере для перемещенных лиц в Германии, откуда переселился в США (Алексеева, 1997: 31).

В 1990-е годы уже на территории Калмыкии начался процесс возрождения традиций калмыцкого казачества. «В Уставе казачьего войска Калмыкии» утверждалось, что восстановление казачества осуществляется на основе равенства буддизма и православия, и в самом казачестве деятельность по нравственному воспитанию молодёжи происходит в союзе православной церкови и буддийского хурула» (Рвачева, 2016: 44). В 1994 г. у казачьего войска Калмыкии появился штатный войсковой лама Ринчен Дагва (Чуматов Владимир Очирович).

Современные калмыки стремятся возродить память о земле предков, посещая малую родину, возводя там культовые сооружения, субурганы (буддийские ступы) (Ламажаа, Намруева, 2018: 215). Среди выходцев из донских калмыков также получила широкое распространение практика посещения прежних калмыцких станиц, которая имеет характер паломничества, так как калмыки прежде всего посещают территории прежних хурулов и места захоронения наиболее уважаемых лам, в частности, Бакши М. Борманжинова.

\section{Заключение}

Таким образом, на Дону в XVIII-XIX веках сложился весьма интересный и, на первый взгляд, парадоксальный феномен в форме калмыцкого буддийского казачества. Может показаться удивительным, что люди, исповедующие столь миролюбивую религию, имели статус казаков - специфического военного сословия. В то же время разгадка этого любопытного факта кроется в самой истории калмыков и их предков ойратов, которые, несмотря на принятие буддизма, известны как один из самых воинственных народов мира. Известно, что калмыки принимали активное участие почти во всех военных конфликтах дореволюционной России и были известны как отважные и умелые воины, поэтому статус военного сословия не вступал в противоречие с их традиционной ментальностью.

Донские калмыки, несмотря на географическую оторванность от основной массы калмыцкого народа и вхождение в состав донского казачества, смогли сохранить свою национальную и конфессиональную идентичность. В условиях иноэтнического, инокультурного окружения буддизм стал ключевым фактором сохранения национальной идентичности у калмыков. Именно он выделял их из состава других народов Области Войска Донского, став символом их этнической самобытности и консолидации.

Среди других причин сохранения у донских калмыков буддийской религии можно выделить традиционный казачий менталитет, отличавшийся терпимостью к другим культурам, в силу чего среди казаков всегда были представители разных конфессий, в том числе и буддисты. Казачья администрация Дона была в свою очередь заинтересована в калмыках, как значительной военной силе, в силу чего религиозные отличия отходили на второй план. Несмотря на попытки ограничить количество хурулов и калмыцкого духовенства, а также поставить под контроль буддийскую церковь донских калмыков, последняя представляя собой достаточно сплоченную и организованную силу, влияние которой на калмыцкое население было значительным. И хотя за годы Советской власти буддизм в Калмыкии пришел в упадок, в 1990-е годы начался процесс его возрождения, в котором значительную роль играли и выходцы из донских калмыков.

\section{СПИСОК ЛИТЕРАТУРЫ}

Алексеева, П. Э. (2002) Богшрахинский аймак и богшрахинцы: краткие исторические очерки. Элиста : Джангар. 255 с.

Алексеева, П. Э. (1997) Станица Граббевская (XVII век - декабрь 1943 г.) : исторический очерк. Элиста : Калмыцкое кн. изд-во. 191 с.

А. М. Позднеев (1851-1920) в память о Бакши-ламе донских калмыков Менке Борманжинове (1855-1919) (по материалам Архива востоковедов ИВР РАН) (2017) // Mongolica-XIX : сборник научных статей по монголоведению посвящается ведущим российским монголоведам, юбилярам 2017 года М. И. Гольману, В. В. Грайворонскому и К. Н. Яцковской. СПб. : Петербургское Востоковедение. 104 с. С. 68-75.

Бакаева, Э. П. (1994) Буддизм в Калмыкии. Историко-этнографические очерки. Элиста : Калмыцкое книжное издательство. 128 с. 
Бакаева, Э. П. (2019) Расширяющееся культурное пространство: пример калмыцкой диаспоры (буддизм и идентичность, миграции и современные технологии) // Новые исследования Тувы. № 3. C. 116-134. DOI: https:/doi. org/10.25178/nit.2019.3.10

Борманджинов, А. (1997) Ламы калмыцкого народа: ламы донских калмыков. Элиста ; М. : Зеленоградский обыватель ; Зареалье. 60 с.

Браиловский, С., Немцов, Н. (1901) Из поездки к донским калмыкам // Исторический вестник. Т. 86. № 11. С. 717-735.

Броневский, В. Б. (1834) Описание Донской земли и Кавказских Минеральных вод : в 4 ч. СПб. : Тип. Экспедиции заготовления государственных бумаг. Ч. ІІІ. 217 с.

Гурий, иеромонах (1911). Донские калмыки и история их христианского просвещения по трудам Казанского миссионерского съезда. СПб. : Издание В. М. Скворцова. 40 с.

Гучинова, Э.-Б. М. (2004) Улица Kalmuk road. История, культура и идентичности калмыцкой общины в США. СПб. : Алетейя. 340 с.

Дорджиева, Г. Ш. (1995) Буддизм и христианство в Калмыкии: Опыт анализа религиозной политики правительства Российской империи (середина XVII - начало XX вв.). Элиста : АПП «Джангар». 126 с.

Дорджиева, Г. Ш. (2012) Буддизм в Калмыкии в вероисповедной политике государства (середина XIX - начало ХХ вв.). Элиста : Изд-во Калмыцкого ун-та. 203 с.

История Калмыкии с древнейших времен до наших дней (2009а) / отв. ред. К. Н. Максимов, Н. Г. Очирова. Элиста : ГУ Издательский дом «Герел». Т. І. 848 с.

История Калмыкии с древнейших времен до наших дней (2009b) / отв. ред. К. Н. Максимов, Н. Г. Очирова. Элиста : ГУ Издательский дом «Герел». Т. ІІІ. 752 с.

Кануков, Х. Б. (1928) Будда-ламаизм и его последствия. Астрахань : Калмиздат «Красный калмык». 94 с.

Крылов, А. Л. (1873) Умственное и нравственное развитие донских калмыков и особенности их быта. Этнографический очерк действ. чл. Обл. Войска Донского стат. ком. А. Крылова. Новочеркасск : Области Войска Донского типография. 58 с.

Ламажаа, Ч. К., Намруева, Л. В. (2018) Субэтнические дифференциации российских этносов (на примере калмыков и тувинцев) // Новые исследования Тувы. № 2. С. 206-226. DOI: https://doi.org/10.25178/nit.2018.2.11

Максимов, К. Н. (2000) История национальной государственности Калмыкии (нач. XVII - XX вв.). М. : Профиздат. 312 с.

Максимов, К. Н. (2002) Калмыкия в национальной политике, системе власти и управления России (XVII-XX вв.). М. : Наука. 524 с.

Максимов, К. Н. (2016) Калмыки в составе донского казачества (XVII - середина XX в.). Ростов-на-Дону : Издательство Южного научного центра РАН. 584 с.

Маслаковец, Н. А. (1874) Физическое и статистическое описание кочевья донских калмыков : в 2 ч. Новочеркасск : Области Войска Донского типография. Ч. 2: Статистическое описание. 95 с.

Номикосов, С. Ф. (1884) Статистическое описание области войска Донского. Новочеркасск : Типография Области Войска Донского. 762 с.

Павловский, С. (1911) Краткие сведения о донских калмыках // Донские епархиальные ведомости. № 36. С. 1001-1008.

Попов, И. И. (1919) Донские калмыки-казаки // Очерки географии Всевеликого Войска Донского / авторсоставитель В. В. Богачев. Новочеркасск : Отдел народного просвещения Всевеликого Войска Донского. 523 с. C. 284-329.

Рвачева, О. В. (2016) Движение за возрождение казачества в Калмыкии в конце XX - начале XXI вв. // Вестник Калмыцкого института гуманитарных исследований РАН. № 2. С. 42-49.

Ремилева, Е. (2010) Ойрат-монголы: Обзор истории европейских калмыков. Weiler : Бертуган. 690 с.

Траилин, Ф. (1872) Санксрин-Курэдэ, священное калмыцкое изображение и сведения о донских калмыках. Новочеркасск : Типография Области Войска Донского. 58 с.

Кольдонга Содном (2018) «Жить свободно по своим обычаям...» : духовное наследие калмыцкой эмиграции / сост., вступ. ст., коммент. Б. А. Бичеева. Элиста : КалмНЦ РАН. 440 с.

Уланов, Н. Э. (1902) Буддийско-ламаистское духовенство донских калмыков, его современное положение. СПб. : Паровая скоропеч. «Восток» М. М. Гутзац. 16 с. 
Уланов, М. С., Бадмаев, В. Н. (2017) Буддизм и право в Калмыцком ханстве (XVII-XVIII вв.) // Юридическая наука и практика: Вестник Нижегородской академии МВД России. № 4. С. 76-81.

Уланов, М. С., Бадмаев, В. Н. (2020) Женское духовенство в истории буддизма у монгольских народов России // Диалог со временем. Вып. 72. С. 195-208.

Ульянов, Д. (1913) Предсказания Будды о доме Романовых и краткий очерк моих путешествий в Тибет в 1904-1905 гг. СПб. : Центральная типо-лит. 118 с.

Цюрюмов, А. В. (2007) Калмыцкое ханство в составе России: проблемы политических взаимоотношений. Элиста : АПП «Джангар». 462 с.

Шовунов, К. П. (1992) Калмыки в составе российского казачества. Элиста : Калмыцкий институт общественных наук. 317 с.

Ulanov, M. S., Badmaev, V. N., Holland, E. C. (2017) Buddhism and Kalmyk secular law in the seventeenth to nineteenth centuries // Inner Asia. No. 19. P. 297-314.

Дата поступления: 01.02.2021 2.

\section{REFERENCES}

Alekseeva, P. E. (2002) Bogshrakhinskii aimak i bogshrakhintsy: kratkie istoricheskie ocherki [Bogshrakhinsky aimak and the Bogshrakhintsy: Brief historical essays]. Elista, Dzhangar. 255 p. (In Russ.).

Alekseeva, P. E. (1997) Stanitsa Grabbevskaia (XVII vek - dekabr' 1943 g.) : istoricheskii ocherk [The stanitsa of Grabbevskaya (the 17th century - December 1943) : A historical essay]. Elista, Kalmyk Publishing House. 191 p. (In Russ.).

A. M. Pozdneev (1851-1920) v pamiat' o Bakshi-lame donskikh kalmykov Menke Bormanzhinove (1855-1919) (po materialam Arkhiva vostokovedov IVR RAN) [A. M. Pozdneev (1851-1920) in memory of the Bakshi Lama of the Don Kalmyks, Menka Bormanzhinov (1855-1919) (Based on the materials of the Archive of Orientalists at the Institute of Oriental Manuscripts of the RAS)] (2017). In: Mongolica-XIX [Mongolica-XIX]: A collection of scientific articles on Mongol studies dedicated to the leading Russian Mongol scholars, anniversary celebrants of 2017, M. I. Gol'man, V. V. Graivoronskii and K. N. Iatskovskaia. St. Petersburg, Peterburgskoe Vostokovedenie. 104 p. Pp. 68-75. (In Russ.).

Bakaeva, E. P. (1994) Buddizm v Kalmykii. Istoriko-etnograficheskie ocherki [Buddhism in Kalmykia. Historical and ethnographic essays]. Elista, Kalmyk Publishing House. 128 p. (In Russ.).

Bakaeva, E. P. (2019) Rasshiriaiushcheesia kul'turnoe prostranstvo: primer kalmytskoi diaspory (buddizm i identichnost', migratsii i sovremennye tekhnologii) [The expanding cultural space: a case study of the Kalmyk diaspora (Buddhism and identity, migrations and modern technologies)]. New Research of Tuva, no. 3, pp. 116-134. (In Russ.). DOI: https://doi.org/10.25178/nit.2019.3.10

Bormandzhinov, A. (1997) Lamy kalmytskogo naroda: lamy donskikh kalmykov [Lamas of the Kalmyk people: Lamas of the Don Kalmyks]. Elista; Moscow, Zelenogradskii obyvatel'; Zareal'e. 60 p. (In Russ.).

Brailovskii, S. and Nemtsov, H. (1901) Iz poezdki k donskim kalmykam [From a trip to the Don Kalmyks]. Istoricheskii vestnik, vol. 86, no. 11, pp. 717-735. (In Russ.).

Bronevskii, V. B. (1834) Opisanie Donskoi zemli i Kavkazskikh Mineral'nykh vod [A description of the Don land and the Caucasian Mineral Waters] : in 4 parts. St. Petersburg, Tip. Ekspeditsii zagotovleniia gosudarstvennykh bumag. Part III. 217 p. (In Russ.).

Gurii, ieromonakh (1911) Donskie kalmyki i istoriia ikh khristianskogo prosveshcheniia po trudam Kazanskogo missionerskogo s"ezda [The Don Kalmyks and the history of their Christian Enlightenment according to the works of the Kazan Missionary Congress]. St. Petersburg, Izdanie V. M. Skvortsova. 40 p. (In Russ.).

Guchinova, E.-B. M. (2004) Ulitsa Kalmuk road. Istoriia, kul'tura i identichnosti kalmytskoi obshchiny v SShA [Kalmuk road Street. History, culture, and identities of the Kalmyk community in the USA]. St. Petersburg, Aletheia. 340 p.

Dordzhieva, G. Sh. (1995) Buddizm i khristianstvo v Kalmykii: Opyt analiza religioznoi politiki pravitel'stva Rossiiskoi imperii (seredina XVII - nachalo XX vv.) [Buddhism and Christianity in Kalmykia: The experience of analyzing the religious policy of the government of the Russian Empire (The mid-17th - early 20th centuries)]. Elista, APP «Dzhangar». 126 p. (In Russ.).

Dordzhieva, G. Sh. (2012) Buddizm v Kalmykii v veroispovednoi politike gosudarstva (seredina XIX - nachalo XX vv.) [Buddhism in Kalmykia in the religious policy of the state (The mid-19th-early 20th centuries)]. Elista, Kalmyk University Publ. 203 p. (In Russ.).

Istoriia Kalmykii s drevneishikh vremen do nashikh dnei [History of Kalmykia from ancient times to the present day] (2009a) / ed. by K. N. Maksimov and N. G. Ochirova. Elista, Publ. House “Gerel”. Vol. I. 848 p. (In Russ.). 
Istoriia Kalmykii s drevneishikh vremen do nashikh dnei [History of Kalmykia from ancient times to the present day] (2009b) / ed. by K. N. Maksimov and N. G. Ochirova. Elista, Publ. House “Gerel”. Vol. III. 752 p. (In Russ.).

Kanukov, Kh. B. (1928) Budda-lamaizm i ego posledstviia [Buddha-Lamaism and its consequences]. Astrakhan, Kalmizdat “Krasnyi kalmyk”. 94 p. (In Russ.).

Krylov, A. L. (1873) Umstvennoe i nravstvennoe razvitie donskikh kalmykov i osobennosti ikh byta. Etnograficheskii ocherk deistv. chl. Obl. Voiska Donskogo stat. kom. A. Krylova [Mental and moral development of the Don Kalmyks and features of their everyday life. An ethnographic essay by the full member of the Statistical Committee of the Province of the Don Cossack Host, A. Krylov]. Novocherkassk, Printing House of the Province of the Don Cossack Host. 58 p. (In Russ.).

Lamazhaa, Ch. K. and Namrueva, L. V. (2018) Subetnicheskie differentsiatsii rossiiskikh etnosov (na primere kalmykov i tuvintsev) [Sub-ethnic differentiations of Russian ethnic groups: the case of Kalmyks and Tuvans]. New Research of Tuva, no. 2, pp. 206-226. (In Russ.). DOI: https://doi.org/10.25178/nit.2018.2.11

Maksimov, K. N. (2000) Istoriia natsional'noi gosudarstvennosti Kalmykii (nach. XVII - XX vv.) [The history of the national statehood of Kalmykia (The early 17th - 20th centuries)]. Moscow, Profizdat. 312 p. (In Russ.).

Maksimov, K. N. (2002) Kalmykiia v natsional'noi politike, sisteme vlasti i upravleniia Rossii (XVII-XX vv.) [Kalmykia in the national policy and the system of government and management of Russia (17th-20th centuries)] Moscow, Nauka. $524 \mathrm{p}$. (In Russ.).

Maksimov, K. N. (2016) Kalmyki v sostave donskogo kazachestva (XVII -seredina XX v.) [Kalmyks as part of the Don Cossacks (17th century - mid-20th century)]. Rostov-on-Don, Publ. House of the Southern Scientific Centre of the RAS. 584 p. (In Russ.).

Maslakovets, N. A. (1874) Fizicheskoe i statisticheskoe opisanie kochev'ia donskikh kalmykov [Physical and statistical description of the Don Kalmyks' nomadism] : in 2 parts. Novocherkassk, Printing House of the Province of the Don Cossack Host. Part 2: Statisticheskoe opisanie [Statistical description]. 95 p. (In Russ.).

Nomikosov, S. F. (1884) Statisticheskoe opisanie oblasti voiska Donskogo [Statistical description of the Province of the Don Cossack Host]. Novocherkassk, Printing House of the Province of the Don Cossack Host. 762 p. (In Russ.).

Pavlovskii, S. (1911) Kratkie svedeniia o donskikh kalmykakh [Brief information about the Don Kalmyks]. Donskie eparkhial'nye vedomosti, no. 36, pp. 1001-1008. (In Russ.).

Popov, I. I. (1919) Donskie kalmyki-kazaki [The Don Kalmyk Cossacks]. In: Ocherki geografii Vsevelikogo Voiska Donskogo [Essays on the geography of the All-Great Don Host] / author-compiler V. V. Bogachev. Novocherkassk, Otdel narodnogo prosveshcheniia Vsevelikogo Voiska Donskogo [Department of Public Education of the All-Great Don Host]. 523 p. Pp. 284-329. (In Russ.).

Rvacheva, O. V. (2016) Dvizhenie za vozrozhdenie kazachestva v Kalmykii v kontse XX - nachale XXI vv. [The Cossack restoration movement in Kalmykia in the late 20th - early 21st centuries]. Vestnik Kalmytskogo instituta gumanitarnykh issledovanii RAN, no. 2, pp. 42-49. (In Russ.).

Remileva, E. (2010) Oirat-mongoly: Obzor istorii evropeiskikh kalmykov [Oirat-Mongols: A review of the history of the European Kalmyks]. Weiler, Bertugan. 690 p. (In Russ.).

Trailin, F. (1872) Sanksrin-Kurede, sviashchennoe kalmytskoe izobrazhenie i svedeniia o donskikh kalmykakh [SanksrinKurede, the sacred Kalmyk image and information about the Don Kalmyks]. Novocherkassk, Printing House of the Province of the Don Cossack Host. 58 p. (In Russ.).

Kol'donga Sodnom (2018) "Zhit' svobodno po svoim obychaiam...» : dukhovnoe nasledie kalmytskoi emigratsii ["To live freely according to their customs...”: The spiritual heritage of the Kalmyk emigration] / comp. by B. A. Bicheev. Elista, Kalmyk Scientific Center of the RAS. 440 p. (In Russ.).

Ulanov, N. E. (1902) Buddiisko-lamaiskoe dukhovenstvo donskikh kalmykov, ego sovremennoe polozhenie [The BuddhistLamaist clergy of the Don Kalmyks, its current state]. St. Petersburg, Parovaia skoropech. «Vostok» M. M. Gutzats. 16 p. (In Russ.).

Ulanov, M. S. and Badmaev, V. N. (2017) Buddizm i pravo v Kalmytskom khanstve (XVII-XVIII vv.) [Buddhism and law in the Kalmyk Khanate (17th-18th centuries)]. Iuridicheskaia nauka i praktika: Vestnik Nizhegorodskoi akademii MVD Rossii, no. 4, pp. 76-81. (In Russ.).

Ulanov, M. S. and Badmaev, V. N. (2020) Zhenskoe dukhovenstvo v istorii buddizma u mongol'skikh narodov Rossii [Female clergy in the history of Buddhism among the Mongolian peoples of Russia]. Dialog so vremenem, vol. 72 , pp. 195-208. (In Russ.).

Ulyanov, D. (1913) Predskazaniia Buddy o dome Romanovykh i kratkii ocherk moikh puteshestvii v Tibet v 1904-1905 gg. [Buddha's predictions about the House of the Romanovs and a brief sketch of my travels to Tibet in 1904-1905]. St. Petersburg, Tsentral'naia tipo-lit. 118 p. (In Russ.). 
Tsiuriumov, A. V. (2007) Kalmytskoe khanstvo v sostave Rossii: problemy politicheskikh vzaimootnoshenii [The Kalmyk Khanate as part of Russia: Problems of political relations]. Elista, APP “Dzhangar”. 462 p. (In Russ.).

Shovunov, K. P. (1992) Kalmyki v sostave rossiiskogo kazachestva [Kalmyks as part of the Russian Cossacks]. Elista, Kalmyk Institute of Social Sciences. 317 p. (In Russ.).

Ulanov, M. S., Badmaev, V. N. and Holland, E. C. (2017) Buddhism and Kalmyk secular law in the seventeenth to nineteenth centuries. Inner Asia, no. 19, pp. 297-314.

Submission date: 01.02.2021. 